\title{
THOMAS HOBBES AND JEAN- JACQUES ROUSSEAU ON LIBERTY AND SLAVERY OF CONSCIENCE IN THE CONTEXT OF CHRISTIAN POLITICAL THEOLOGY
}

\author{
Mika Ojakangas
}

\section{Introduction}

In his recently published Civil Religion, Ronald Beiner suggests that Hobbes's intention was not to "detheocratize" but rather to "retheocratize" politics, because only through (nominally Christian) theocratic politics can the sovereign to strip Christianity of the otherworldly teachings that threaten temporal authority. According to Beiner, even Jean-Jacques Rousseau's famous civil confession of faith pales into insignificance when compared to Hobbes theocratic intentions: "Thus Hobbes would no doubt argue against Rousseau's civil religion that it is not theocratically ambitious enough." ${ }^{1}$ In this article, I argue that

1 Ronald Beiner, Civil Religion: A Dialogue in the History of Political Philosophy (Cambridge: Cambridge University Press, 2011), p. 57.In “Thomas Hob- 


\section{Thomas Hobbes and Jean-Jacques Rousseau}

Hobbes intention was neither to "detheocratize" nor to "retheocratize" politics, but rather to depoliticize religion.Instead, it is precisely Rousseau who introduced a radically "theocratic", or rather, religiousmodel of politics, because unlike the Hobbesian commonwealth Rousseaun theory of politics abolishes the liberty of conscience from the body politic.Hobbes was perhaps one of the most obvious anti-liberals among the Reformed political theorists, but he was still able to ask what infidel king was so unreasonable as to put to death a subject whose beliefs differ from the beliefs of the sovereign, whereas Jean-Jacques Rousseau declared that every reasonable sovereign should indeed kill such a person. Mere obedience was no longer enough. According to Hobbes, a private man "has alwaies the liberty, (because thought is free,) to beleeve, or not beleeve in his heart,"'but as we shall see, Rousseau demanded that one has to believeand even sincerely love the state and its laws- even in peril of one's life.

In the article, I first briefly examine the history of Christian ideas concerning civil authority, obedience, freedom, and their relationship, arguing that there is apermanent core in the Christian doctrine of politics and that it pertains to the Christian conception of man as a divided being. The Christian man is composed of the inner and the outer man radically separated from each other to the effect that the outer

bes contra Liberty of Conscience," Johan Tralau makes a similar though perhaps even bolder suggestion, as he claims that Hobbes's theory of the state does not entail liberty of conscience at all. Johan Tralau, "Hobbes contra Liberty of Conscience," Political Theory, vol. 39, no. 1 (2011), pp. 5884. Tralau's argument is based on the premise that Hobbes undertakes a fundamental revision of the concept of conscience. In this respect, I rather agree with Mark Hanin who in his recent article has shown that Hobbes's account of conscience is quite traditional. Mark Hanin, "Thomas Hobbes's Theory of Conscience," History of Political Thought, vol. 33, no. 1 (2012), pp. 55-85. Although Hanin is also right in emphasizing that Hobbes relied on conscience to establish and sustain civil life, I shall argue that unlike Rousseau Hobbes did not subjugate conscience to the laws of the state. On that his views were again rather traditional and in accord with the Lutheran accounts of the relationship between religion, conscience, and politics in particular.

2 Thomas Hobbes, Leviathan (Cambridge: Cambridge University Press, 1991), 3.37, p. 306. 


\section{Mika OJakangas}

man, meaning the body and flesh, is obliged to obey all authorities (Rom. 13), whereas the inner man, meaning the soul and conscience, is free from mundane obligations and accountable to God alone (Acts 5:29). I then analyse Hobbes's theory of the state in the light of this Christian background, arguing that Hobbes's theory of the state is still "Christian"in the sense that the conscience of the Hobbesian citizen is free form the law. He is bound to obey the law, even conscientiously, but not to believe in it in her heart, let alone love it. Finally, I examine Rousseau's civil confession of faith in Social Contract and argue that it is here rather than in Hobbes's theory of the state that the dichotomy between the inner self and the state is abrogated, because the distinction between outer obedience and inner faith was transformed into the obedience based on inner faith.

\section{Christian Obedience}

In the Social Contract, Jean-Jacques Rousseau famously proclaims that nothing is more contrary to the social spirit than Christianity, for it has eradicated ancient liberty and republican freedom from the world. Christianity preaches nothing but "servitude and submission. Its spirit is too favourable to tyranny for tyranny not to take advantage of it. True Christians are made to be slaves." ${ }^{3}$ In a sense, Rousseau is right. We know what Apostle Paul says in the Romans 13:

Let every person be subject to the governing authorities. For there is no authority (exousia) except from God, and those that exist have been instituted by God. Therefore he who resists the authorities resists what God has appointed, and those who resist will incur judgment. For rulers are not a terror to good conduct, but to bad. Would you have no fear of him who is in authority? Then do what is good, and you will receive his approval, for he is God's servant for your good. But if you do wrong, be afraid, for he does not bear the sword in vain; he is the servant of God to execute his wrath on the wrongdoer. Therefore one must to subject oneself (hypotassō), not only to avoid God's wrath but also for the sake

3 Jean-Jacques Rousseau, The Social Contract, trans. M. Cranston (London: Penguin, 1968), 4.8, p. 184. 
Thomas Hobbes and Jean-JacQues Rousseau

of conscience (diatēnsyneidēsin).

Although the passage might be an interpolation, it has profoundly influenced subsequent Christian views and doctrines concerning secular authority. In Summa Theologiae, Thomas writes: "The order of justice requires that subjects obey their superiors, else the stability of human affairs would cease. Hence faith in Christ does not excuse the faithful from the obligation of obeying secular princes." 4 The doctrine reached its apex in Luther's writings and especially in orthodox Lutheranism. According to Luther, a good Christian always obeys secular authorities. Every Christian is also "under obligation to serve and assist the sword by whatever means" he can. ${ }^{5}$ The sword must be served and assisted because authorites are ordained by God. ${ }^{6}$ And these authorities must be obeyed and served irrespective of whether they act justly or unjustly: "Christians should not, under the pretence of Christian religion," refuse to obey authorities "even if they are wicked." In subsequent orthodox Reformed circles, this unreserved obedience became gradually a dogma. William Tyndale writes: "The powers that be are ordained by God. Whosoever resists power resists the ordinance of God. They that resist, shall receive to them self damnation." ${ }^{8}$ Every temporal power or authority is the minister of God, Tyndale continues, and therefore everybody is obliged to obey him, not out of fear, but for the sake of conscience - both of your own and that of your neighbour. This must be done even if the temporal power or authority in question

4 Thomas Aquinas, Summa TheologicaIIaIIae, q. 104, in The Summa Theologica of St. Thomas Aquinas, ed. J. Kenny (London: Burns Oates and Washbourne, 1920), accessed August 24, 2012. http://www.newadvent.org/summa/

5 See Martin Luther, Temporal Authority: To What Extent it should be Obeyed, in Luther's Works in 55 Volumes, general ed. Helmut T. Lehmann, vol. 45 (St. Louis, Minneapolis: Concordia Publishing House, Fortress Press, 19571986), p. 95.

6 "What powers there are have been instituted by God." Martin Luther,Lectures on Romans, in Luther's Worksin 55 Volumes, general ed. Helmut T. Lehmann, vol. 25 (St. Louis, Minneapolis: Concordia Publishing House, Fortress Press, 1957-1986), 13:1, pp. 109-110.

7 Luther, Romans 13:1, p. 110.

8 William Tyndale, The Obedience of A Christian Man, ed. D. S. Daniel (London: Penguin Books, 2000), p. 36. 


\section{Mika OJakangas}

were the "greatest tyrant in the world," because even as a tyrant he is a "great benefit of God and a thing wherefore thou ought to thank God highly."' In Calvin's Institutes, we find plenty of similar passages, but one example suffices here:

Even an individual of the worst character, one most unworthy of all honour, if invested with public authority, receives that illustrious divine power which the Lord has by his word devolved on the ministers of his justice and judgment, and that accordingly, in so far as public obedience is concerned, he is to be held in the same honour and reverence as the best of kings. ${ }^{10}$

\section{Christian Freedom}

Yet even if Christianity has preached obedience to earthly authorities, the political aspect of Christianity cannot be reduced to this doctrine. With regard to Christian politics, equally important as the Romans 13 has been the famous passage in the Acts 5:29, repeated time and again by the Christians throughout Western history. Interrogated by the high priest who charged them not to preach in the name of Christ, the Apostles replied as one voice: "We must obey God rather than men." What then has it meant to obey God rather than men? On the one hand, it has meant that men must obey the Church and its representatives rather than civil authorities. On the other hand, it has meant that men must obey their consciences rather than the opinion of other men, even if they were the representatives of the Church, as the Church itself preached that it is God who speaks in our consciences and taught that it is sin to act against it. In point of fact, almost all significant religious revolts against the authority of the Church in the late medieval world revolved around this orthodox doctrine: contra conscientiam agere peccatum est. In his Sermons, John Wyclif appealed to his conscience in his struggle against ecclesiastical authority, asserting that the final forum of merit

9 Tyndale, Obedience of a Christian Man, p. 41, pp. 50-51.

10 John Calvin, Institutes of the Christian Religion, trans. H. Beveridge (Grand Rapids: Eerdmans Publishing Company, 1989), 4.20.25, p. 671. 


\section{Thomas Hobbes and Jean-Jacques Rousseau}

"rests in my own conscience" (in consciencia mea propria stabilitur). ${ }^{11}$ Similarly, when Jan Hus, in 1415, was accused of heresy for holding Wyclif's doctrine of remanence, Hus refused to recant, not because he held fast to Wyclif's doctrine contrary to the teachings of the Council, but because abjuring something that one has never held would have meant for him acting against his conscience - and to act against conscience is a mortal $\sin .{ }^{12}$ The most famous case is of course Luther. It was precisely the contra conscientiam doctrine that he appealed to when accused of heresy at the Diet of Worms: "My conscience is captive to the Word of God. I cannot and will not retract anything, since it is neither safe nor right to go against conscience. I cannot do otherwise, here I stand, may God help me,Amen." ${ }^{13}$ As a doctrinal source for the religious upheavals of the $16^{\text {th }}$ and the $17^{\text {th }}$ century Europe, this single doctrine was perhaps more important than any of the theological doctrines introduced by Luther himself.

Second, since late antiquity, the theologians had opined that all human laws must be compatible with natural law and if this has not been the case, the human law has no power of binding conscience. People have no obligation, says Aquinas, to obey any authorities whose laws are contrary to natural law. ${ }^{14}$ Such a law has no "power of binding conscience," 15 because "human law cannot impose its precepts in a Divine court, such as is the court of conscience." ${ }^{16}$ Natural law is given by God through the creation and we must obey God rather than men:

Laws may be unjust through being opposed to the Divine good: such are the laws of tyrants inducing to idolatry, or to anything else contrary to the Divine law: and laws of this kind must nowise be observed, be-

11 Cited in Paul Strohm, Conscience: A Very Short Introduction (Oxford: Oxford University Press, 2011), p. 16.

12 Jan Hus, The Letters of John Hus, trans. R. M. Pope (London: Hodder and Stoughton, 1904), p. 217.

13 Martin Luther, "The Speech of Dr. Martin Luther before the Emperor Charles and Princes at Worms," in Luther's Works in 55 Volumes, general ed. Helmut T. Lehmann, vol. 32 (St. Louis, Minneapolis: Concordia Publishing House, Fortress Press, 1957-1986), pp. 112-113.

14 Aquinas, Summa Theologica, IIaIae, q. 94, a. 4.

15 Aquinas, Summa Theologica, IIaIae, q. 96, a. 4.

16 Aquinas, Summa Theologica, IIaIae, q. 94, a. 4. 


\section{Mika OJakangas}

cause, as stated in Acts 5:29, "we ought to obey God rather than man."17

Further, he argues that the subjects are not obliged to obey the ruler or his laws if he acts contrary to the purpose of his mandate: if the ruler was appointed to preserve virtue, then for him to command his subjects to perform acts of vice is illegitimate and the subject is not only not bound to obey, but obliged to disobey, "as in the case of holy martyrs who suffered death rather than obey the ungodly commands of tyrants." ${ }^{18}$ Finally, Aquinas alludes, quoting Cicero, that slaying such a tyrant is a virtuous act, and maintains that a subject is not bound to obey a law that "inflicts unjust hurt on its subjects," for example by imposing excessive taxes, provided he avoids "giving scandal or inflicting a more grievous hurt." ${ }^{19}$ In like manner, Francesco Suárez argues that laws incompatible with natural law, which is "truly and properly divine law," ${ }^{20}$ are null and void. He also maintains that people have an inalienable right to resist unjust rulers who violate divine law of nature reasserting his argument by referring to the sentence in the Acts: "One must obey God rather than men."

Not even Reformed theologians were absolutely categorical with obedience. Luther holds that people are not bound to obey a prince if he commands something that is wrong ("for it is not one's duty to do wrong"), ${ }^{21}$ that tyrants are not to be tolerated, and that every Christian is free to use his freedom to oppose them, at least in word:

Use your freedom constantly and consistently in the sight of and despite the tyrants and the stubborn so that they also may learn that they are impious, that their laws are of no avail for righteousness, and that they had no right to set them up. ${ }^{22}$

17 Aquinas, Summa Theologica, IIaIae, q. 96, a. 4.

18 Thomas Aquinas, Political Writings, ed. R. W. Dyson (Cambridge: Cambridge University Press, 2002), pp. 73-74.

19 Aquinas, Summa TheologicaIIaIae, q. 96, a. 4.

20 Francisco Suárez, A Treatise on Laws and God the Lawgiver, in Francisco Suárez, Selections from Three Works, ed. Gwladys L. Williams et al., vol. 2 (Oxford:The Clarendon Press, 1944), 2.6.13, p. 198.

21 Luther, Temporal Authority, p. 125.

22 Martin Luther, The Freedom of a Christian, in Luther's Works in 55 Volumes, general ed. Helmut T. Lehmann, vol. 31 (St. Louis, Minneapolis: Concordia 


\section{Thomas Hobbes and Jean-Jacques Rousseau}

Similarly, Calvin admits that God sometimes allows and indeed induces resistance against the fury of tyrants. Quoting Acts 5:29, Calvin proclaims:

If they command anything against Him let us not pay the least regard to it, nor be moved by all the dignity which they possess as magistrates - a dignity to which no injury is done when it is subordinated to the special and truly supreme power of God. ${ }^{23}$

Moreover, they both defend their arguments by referring to natural law, which is, as Calvin put it, is "the aim, the rule and the end of all laws." ${ }^{24}$ The legitimacy of all human laws and institutions, Calvin continues, depends on how they agree with this law and with "conscience which God has engraved upon the minds of men." ${ }^{25}$ Similarly, when Calvin's successor Theodore Beza, two years after the St Bartholomew's Massacre, published a pamphlet De jure magistratum against tyranny in religious matters, he not only referred to the passage in the Acts, but also used the Stoic-Catholic doctrine of natural law in order to justify his argument - the law so firmly "established and so lasting that nothing which is openly opposed and repugnant to it should be regarded as just and valid between men." ${ }^{26}$ According to Beza, magistrates must not be obeyed if what they command is impious or unjust, impious referring to anything contradicting the first tablet of God's law and unjust to anything that prevents or forbids one from rendering his neighbour what is his due "by the law of nature." ${ }^{27}$ Althusius in turn argues, like Calvin, ${ }^{28}$

Publishing House, Fortress Press, 1957-1986), p. 374.

23 Calvin, Institutes, 4.20.32, p. 675.

24 Calvin, Institutes, 4.20.16, p. 664; see Martin Luther, Lectures on Galatians, in Luther's Works in 55 Volumes, general ed. Helmut T. Lehmann, vols. 26-27 (St. Louis, Minneapolis: Concordia Publishing House, Fortress Press, 19571986), 5:14, p. 53.

25 Calvin, Institutes, 4.20.16, p. 664.

26 Theodore Beza, De jure magistratuum, q. 6, ed. Patrick S. Poole, accessed August 24, 2012, http://www.constitution.org/cmt/beza/magistrates. htm

27 Beza, De jure magistratuum, q. 3.

28 See Calvin, Institutes, 4.20.32, pp. 675-6. 


\section{Mika OJakangas}

that it is legitimate for the ephors and popular magistrates to depose a tyrant "as quickly as a fire must be dowsed by those who see it," if he despises that law of nature on which the written laws must be based. ${ }^{29}$ William Perkins went as far as Aquinas, asserting that if a command of the prince contradicts the Word and the Law of God, "then is there no bond of conscience at all, but contrariwise men are bound in conscience not to obey." ${ }^{30}$ In fact, he went further than Aquinas, because Thomas held that the subjects should at least occasionally obey unjust rulers in order to avoid scandal, while Perkins maintains that God's Word and Law is to be obeyed, "though we should offend all men, yea lose all men's favour, and suffer the greatest damage that may be, even the loss of our lives." ${ }^{31}$ This was the opinion the Puritan priest William Ames as well. According to him, no human command, whether ecclesiastical or political, can override the law of God: "It is that the Law of God only doth bind the conscience of man," which means that the conscience cannot "submit itself unto any creature without idolatry." 32 Eventually, as we have already seen, the authority of conscience surpassed even the authority of the Word. Because of this wonderful faculty, says Samuel Ward of Ipswich, man no longer needs any external guidance, not to mention external authority. The force and power of conscience is greater than any other power on earth and even the power of angels. Therefore, we must, as the Apostle Paul allegedly suggested, follow the dictate of conscience rather than the dictates of angel, potentate or prelate, "yes, even of the Apostle himself." 33

29 Johannes Althusius, Politica: Politics Methodically Set Forth and Illustrated with Sacred and Profane Examples, trans. F. Carney (Indianapolis: Liberty Fund, 1995), 28, p. 94.

30 William Perkins, A Discourse of Conscience, in William Perkins: His Pioneer Works on Casuistry, ed.T. F. Merrill (Nieuwkoop: B. De Graaf, 1966), p. 34.

31 Perkins, Discourse of Conscience, p. 10.

32 William Ames, Conscience with the Power and Cases Thereof (Leyden: W. Christiaens, E. Griffin, J. Dawson, 1639), p. 6.

33 Samuel Ward, Balme from Gilead to Recouer Conscience (London: Roger Jackson, 1616), p. 49. 
Thomas Hobbes and Jean-Jacques Rousseau

\section{The Christian Doctrine of a Divided Man}

In fact, when Rousseau laments Christianity, it is not the Christian preaching of submission that annoys him the most. More disturbing is the Christian teaching that "God cannot and will not permit anyone but himself to rule over the soul. ${ }^{34}$ It is this freedom of the soul and conscience that is Rousseau's main enemy. Christianity detaches the soul and conscience from the body politic and its laws and it is precisely for this reason that Rousseau considers Christianity essentially an anti-political doctrine:"This religion, having no specific connexion with the body politics, leaves the law with only the force the law itself possesses, adding nothing to it," that is, without endowing it with such holiness that might bind the "hearts of the citizens to the state." ${ }^{35}$ Here Rousseau indeed captures the essential. Christianity, at least before the rise of nationalism in the West, if we are allowed to speak at the same level of generalization as Rousseau, is not only a doctrine of political slavery but it cannot be reduced to a revolutionary political movement either. In terms of politics, it is an ideology of profanation. The hearts and consciences of Christians are not bound to the state but to God and this entailsthe relativity of everything present. This is not to say that there would be no Christian doctrine of obedience or that there is no idea of radical freedom in Christianity. As we have seen, they are both part and parcel of this religion, but perhaps the most unique political feature of this religion is the way how it combines the elements articulated in the Romans 13 and the Acts 5:29. It combines them by dividing man in two.

Rousseau is thus perfectly correct: the Christian man is not a unity. It is, as already Paul's theological anthropology implies, a combination of the inner (esōhēmōn) and the outer man (exōhēmōnanthrōpos) strictly separated from and opposed to each other (2 Cor. 4:16). In the Christian tradition, it is the inner man, meaning man's soul and conscience ("renewed day by day," as Paul says) that has been free from mundane obligations and accountable to God alone, whereas the outer man, meaning the body and flesh ("wasting away," to quote Paul again), has belonged to this world and has been bound by earthly relations and obligations. In other words, it has been the body that has had the duty to observe the Romans 13 , whereas

34 Luther, Temporal Authority, p. 105.

35 Rousseau, Social Contract, 4.8, 182. 


\section{Mika OJakangas}

the proclamation in the Acts 5:29 relates to the soul alone. This distinction is present already in the writing of the Fathers and it can be found in the Scholastics as well. Thomas Aquinas writes: "In matters pertaining to the inward movement of the will man is not bound to obey man, but God alone. Man is, however, bound to obey man in things which are to be done outwardly by means of the body." ${ }^{36}$ In medieval and early modern Catholicism, this doctrine was usually restricted to the realm of secular power, whereas the Church, which was not merely a human institution, had power over the soul and conscience as well. With the rise of Protestantism, however, both the authority of the Church and the examination of conscience were increasingly, though not of course entirely, called into question.Now the Word of God replaced the authority of the Church: "We believe and are at peace in our conscience, we run not hither and thither for pardon, we trust not in this friar or that monk neither in anything save in the word of God only." ${ }^{37}$ This meant that the Protestants, notably Luther himself, extended the Pauline division between the inner and the outer man to the ecclesiastical sphere as well, arguing that neither secular nor ecclesiastical authorities are entitled to rule over the soul and conscience of man: "Among Christians there shall and can be no authority," ${ }^{38}$ because "every Christian is by faith so exalted above all things that, by virtue of a spiritual power, he is lord of all things without exception." ${ }^{39}$ However, it is the conscience of the Christian that is exalted above all things, whereas the outward man, the body, is subjected to all laws and authorities, particularly to the secular ones: "The conscience must be free from the law, but the body must obey the law." ${ }^{00}$ John Calvin went along with Luther: "We see how the law, while binding the external act, leaves the conscience unbound." Perkins put it as thus: "Magistrate indeed is an ordinance of God to which we owe subjection, but how far subjection is due, there is the question. For body and goods and outward conversation, I grant all: but a subjection of conscience to men's laws, I deny." ${ }^{42}$ Similarly, Bishop Sanderson writes:

36 Aquinas, Summa Theologica, IIaIIae, q. 104, a. 5.

37 Tyndale, Obedience of A Christian Man, p. 147.

38 Luther, Temporal Authority, p. 117.

39 Luther, Freedom of a Christian, p. 354

40 Luther, Galatians 2:13, p. 114.

41 Calvin, Institutes, 3.19.16, p. 142.

42 Perkins, Discourse of Conscience, p. 26. 


\section{Thomas Hobbes and Jean-Jacques Rousseau}

He who alone knows the inward motions of conscience, $\mathrm{He}$ only has a power of prescribing a law to it (for the law never determines or judges of things unknown), but God only, the Searcher of hearts, can discover the inwards motions of the Mind and Conscience; therefore He has the sole right of imposing the law, or laying an obligation upon it. Hence it is that the laws of men oblige only the outward motions of the body to an outward conformity. ${ }^{43}$

True, these Protestants also held that one must, as the Apostle Paul had taught in the Romans 13, to subject oneself to laws and authorities, "not only to avoid God's wrath but also for the sake of conscience (diatēnsyneidēsin)." Yet, for them, the dictum "for the sake of conscience" did not mean that the law extends its power into conscience. This may sound paradoxical but for the early Reformed theologians this paradox was not unresolvable. According to Calvin, one is obliged to keep the law conscientiously because it is enacted by an authority and all authority is from God, but individual laws do not reach the conscience, meaning the internal government of the soul:

The first thing to be done here is to distinguish between the genus and the species. For though individual laws (loy en particulier) do not reach the conscience, yet we are bound by the general command of God, which enjoins us to submit to magistrates. And this is the point on which Paul's discussion turns: magistrates are to be honoured, because they are ordained of God (Rom. 13:1). Meanwhile, he does not at all teach that the laws enacted by them reach to the internal government of the soul (regime spirituel des ames), since he everywhere proclaims that the worship of God, and the spiritual rule of living righteously, are superior to all the decrees of men. ${ }^{44}$

In a similar vein, Perkins argues that men are subject to magistrates "for the sake of conscience" but not "in conscience," ${ }^{45}$ whereas Sander-

43 Robert Sanderson, Lectures on Conscience and Human Law, ed. C. H. R. Wordsworth (London: Rivingtons, 1877), p. 93.

44 Calvin, Institutes, 4.10.5, p. 417.

45 Perkins, Discourse of Conscience, p. 26. 


\section{Mika OJakangas}

son believes that if the obligation of conscience derives from the thing commanded, the liberty of conscience is violated, but if it derives from the sovereign's lawful authority to command, then the inward liberty of conscience remains uninjured. ${ }^{46}$ Hence, according to Calvin, Perkins, and Sanderson, there is no contradiction between the obligation that the laws and the commands of human authorities be obeyed for the sake of conscience and the idea that these laws and commands do not reach the consciences of men - consciences that are not subject to any other authority than that of God alone.

\section{Hobbes contra Rousseau}

It is in this perspective that we must read early modern Protestant political theory, including Thomas Hobbes' theory of the state. According to Rousseau, of all Christian authors Hobbes has been the only one daring to propose a restoration of the unity of religion and politics, without which neither the state nor the government will ever be solidly constituted. ${ }^{47}$ This may be true, but unlike Rousseau, Hobbes did not propose to unite the Christian man. On the contrary, like his Protestant fellows, he fully subscribed to the idea that the law obliges the outward man alone, while the soul and conscience must be left intact by power and the law: "There ought to be no Power over the Consciences of men." ${ }^{48}$ In other words, he maintains, like Luther and his followers, that the conscience of man is free from all laws. Referring to his contemporary Aristotelian Scholastics, Hobbes writes:

There is another error in their civil philosophy (which they never learned of Aristotle, nor Cicero, nor any other of the Heathen) to extend the power of the law, which is the rule of actions only, to the very thoughts, and consciences of men. ${ }^{49}$

46 Sanderson, Lectures on Conscience, p. 164.

47 Rousseau, Social Contract, 4.8, p. 180.

48 Hobbes, Leviathan, 4.47, p. 480.

49 Hobbes, Leviathan, 4.46, p. 471. 
Thomas Hobbes and Jean-Jacques Rousseau

To be sure, Hobbes also holds that the laws of nature and hence, sovereign's commands, are a "matter of conscience" and one should act as the law commands, not because of the penalty attached to the law but "for the sake of the law." ${ }^{50}$ Yet, not unlike his Protestant predecessors, Hobbes thought that the law obliges in forointerno because the law is the sovereign's authoritative command, but materially it does not extend its power in men's consciences, "where not Man, but God raigneth." 51 One is obliged to keep the law conscientiously because it is enacted by the sovereign, but nobody is obliged to believe in his heart or to accuse oneself if one's beliefs, thoughts, and opinions do not accord with particular laws, ${ }^{52}$ "for mensbeliefe, and interior cogitations, are not subject to the command, but only to the operation of God, ordinarly, or extraordinarly." ${ }^{33}$ Admittedly, for Hobbes, the power of conscience was not greater than any other power on earth, as one of the very aims of his theory of the state was to downplay such conception. Yet this does not entail that Hobbes's intention was to "retheocratize" politics, as Beiner suggests..$^{54}$ Instead, Hobbes's intention was to depoliticize religion and expulse religious zealots and religious feelings from the sphere of politics.

Indeed, if there is a contradiction between the Christian and the Rousseaun republican political teaching, it is not that the former preaches slavery and the latter freedom but rather that while the Christian and especially the Reformed political teaching leaves the conscience intact, the republican doctrine penetrates to its core. In the Rousseaun republic, the law cannot be a mere rule of action. It must bind the hearts of the citizens to the state. Man is no longer divided in two, whereby the conscience belongs to God and the body to the state, for both must now be definitely and entirely subjected to the service of the state. This is the backdrop of Rousseau's famous civil confession of faith necessary in every well-ordered state:

There is thus a profession of faith which is purely civil and of which it is the sovereign's function to determine the articles, not strictly as

50 Thomas Hobbes, On the Citizen, ed. E. Tuck (Cambridge: Cambridge University Press, 1998), 4.21, p. 64.

51 Hobbes, Leviathan, 2.30, p. 244.

52 Hobbes, Leviathan, 4.46, p. 471.

53 Hobbes, Leviathan, 2.26, p. 198.

54 Beiner, Civil Religion, p. 57. 


\section{Mika OJakangas}

religious dogmas, but as sentiments of sociability (sentiments de sociabilité), without which it is impossible to be either a good citizen or a loyal subject. Without being able to oblige anyone to believe these articles, the sovereign can banish from the state anyone who does not believe them; banish him not for impiety but as an antisocial being, as one unable sincerely to love law and justice, or to sacrifice, if need be, his life to his duty. If anyone, after having publicly acknowledged these same dogmas, behaves as if he did not believe in them, then let him be put to death, for he has committed the greatest crime, that of lying before the law. ${ }^{55}$

We can clearly see here the difference between Luther and Hobbes on the one hand, and Rousseau on the other. For both Luther and Hobbes, it was enough that the subjects obeyed the law in their conduct, but Rousseau thought that a citizen incapable of sincerely loving (incapable d'aimer sincèrement) the laws of the state and of sacrificing (immoler) himself for them is not a citizen at all but an outlaw who could be banished from the state. Here and not in Hobbes we find a conscience that is no longer free in the sense that it can be detached from state regulation. Hobbes asked what "infidel king is so unreasonable" who puts to death a subject whose beliefs differ from the beliefs of the sovereign, ${ }^{56}$ but Rousseau declares that every reasonable sovereign should indeed kill such a person. In the Hobbesian state subjects were bound to obey the law, but not to believe in it, while in the Rousseaun state they are precisely men's beliefs and interior cogitations that are subject to the commands. Thus, it was not with Hobbes but with such a republican theorists of the state as Rousseau that the dichotomy between outer obedience and inner faith was transformed into the obedience based on inner faith.

This is not to say that Hobbes would have not called into question the authority of conscience in favour of the sovereign's command in his political theory. In this respect, he was as conservative as Philip Filmer, the author of the famous Patriarcha, defending the divine rights of kings. In point of fact, Hobbes' argument in Leviathan is precisely the same

55 Rousseau, Social Contract, 4.8, p. 186.

56 Hobbes, Leviathan, 3.43, p. 414. 
Thomas Hobbes and Jean-Jacques Rousseau

as Filmer's. In his criticism of Philip Hunton's $A$ Treatise of Monarchy in which Hunton, one of the most important parliamentarian pamphleteers in the Civil War, had argued that "resistance ought to be made, and every man must oppose or not oppose, according as in conscience he can acquit or condemn the acts of his governor,", ${ }^{57}$ Filmer writes: "Such a conclusion fits well with anarchy," for it takes away "all government and leaves every man to his own conscience." It makes man "independent in state," rendering all authority illegitimate ${ }^{58}$ On the other hand, if we compare Hobbes with Rousseau, it is almost impossible not to recognize a significant difference. It may be true that the Hobbesian theory of the state is the "root of Rousseau's democratic theory," as Reinhart Koselleck claims, ${ }^{59}$ but there is still a decisive gap between Hobbes and Rousseau. In Rousseau's Social Contract, we encounter a state in which the conscience is no longer an instance which opens up a transcendent dimension within the immanence of political order, as it had been in the Christian tradition, but neither is it an instance which may remain in peace in the private sphere, as in early modern political theory. It is, as it was for Hegel, something that must be incorporated firmly into the immanent political order itself:

If political principles and institutions are divorced from the realm of inwardness, from the innermost shrine of conscience (Heiligthum des Gewissens), from the still sanctuary of religion, they lack any real centre (wirklicher Mittelpunkt) and remain abstract and indeterminate. ${ }^{60}$

This is not to say that these philosophers would have rejected religious liberty of conscience. They usually defended it ardently. What they rejected was the Christian-Hobbesian presumption that the conscience and the state can be separated. What they sought was the ab-

57 Cited in Robert Filmer, The Anarchy of a Limited or Mixed Monarchy, in Patriarcha and Other Writings, ed. J. P. Sommerville (Cambridge: Cambridge University Press, 1991), p. 154.

58 Filmer, Anarchy, p. 154.

59 Reinhart Koselleck, Critique and Crisis (Cambridge, MA: MIT Press, 1988), p. 34, footnote 38.

60 G.W. F. Hegel, The Philosophy of History, trans. J. Sibree (Kitchener: Batoche Books, 2001), p. 52. Translation modified. 


\section{Mika OJakangas}

rogation of the distinction between the inner self and political institutions, because they, as Niccolo Machiavelli before them, wanted to capture the energy of religious conscience and to put it into the service of the state. Therefore, it is here rather than in the Hobbesian theory of the state that the distinction between the inner self and political institutions is abrogated. Compared to Rousseau and Hegel, Hobbes still remained a "Christian," tied to the Christian tradition of political thought. In this sense, Carl Schmitt was right. Hobbes did not fully succeed in restoring the "original unity" of politics and religion. ${ }^{61}$ Perhaps this was not even his intention.

\section{Bibliography}

Althusius, Johannes. Politica: Politics Methodically Set Forth and Illustrated with Sacred and Profane Examples. Translated by F. Carney. Indianapolis: Liberty Fund, 1995.

Ames, William. Conscience with the Power and Cases Thereof.Leyden:W. Christiaens, E. Griffin, J. Dawson, 1639.

Beiner, Ronald. Civil Religion: A Dialogue in the History of Political Philosophy. Cambridge: Cambridge University Press, 2011.

Beza, Theodore. De jure magistratuum. Edited by Patrick S. Poole.Accessed August 22, 2012.http://www.constitution.org/cmt/beza/magistrates. htm

Calvin, John. Institutes of the Christian Religion.Translated by H. Beveridge. Grand Rapids: Eerdmans Publishing Company, 1989.

Filmer, Robert. The Anarchy of a Limited or Mixed Monarchy, in Patriarcha and OtherWritings.Edited by J. P. Sommerville (Cambridge: Cambridge University Press, 1991).

Hanin, Mark. "Thomas Hobbes's Theory of Conscience." History of Political Thought, vol. 33, no. 1, Spring 2012, pp. 55-85.

Hegel, G. W. F. The Philosophy of History. Translated by J. Sibree. Kitchener: Batoche Books, 2001.

Hobbes, Thomas.Leviathan. Cambridge: Cambridge University Press, 1991.

61 Carl Schmitt, TheLeviathan in the State Theory of Thomas Hobbes (Westport: Greenwood Press, 1996), p. 55. 


\section{Thomas Hobbes and Jean-Jacques Rousseau}

Hobbes, Thomas. On the Citizen.Edited by E. Tuck. Cambridge: Cambridge University Press, 1998.

Hus, Jan. The Letters of John Hus. London: Hodder and Stoughton, 1904.

Koselleck, Reinhart. Critique and Crisis. Cambridge: MIT Press, 1988.

Luther, Martin. "The Speech of Dr. Martin Luther before the Emperor Charles and Princes at Worms.'In Luther's Works in 55 Volumes. General editor Helmut T. Lehmann.Vol. 32. St. Louis, Minneapolis: Concordia Publishing House, Fortress Press, 1957-1986.

Luther, Martin. Lectures on Galatians.In Luther's Works in 55 Volumes. General editor Helmut T. Lehmann. Vols. 26-27. St. Louis, Minneapolis: Concordia Publishing House, Fortress Press, 1957-1986.

Luther, Martin. Lectures on Romans. In Luther's Works in 55 Volumes.General editor Helmut T. Lehmann.Vol. 25. St. Louis, Minneapolis: Concordia Publishing House, Fortress Press, 1957-1986.

Luther, Martin. Temporal Authority: To What Extent it should be Obeyed. In Luther's Works in 55 Volumes. General editor Helmut T. Lehmann. Vol. 45. St. Louis, Minneapolis: Concordia Publishing House, Fortress Press, 1957-1986.

Luther, Martin. The Freedom of a Christian.In Luther's Works in 55 Volumes.General editor Helmut T. Lehmann.Vol. 31. St. Louis, Minneapolis: Concordia Publishing House, Fortress Press, 1957-1986.

Perkins, William.A Discourse of Conscience. In William Perkins: His Pioneer Works on Casuistry, edited by T. F. Merrill. Nieuwkoop: B. De Graaf, 1966.

Rousseau, Jean-Jacques. TheSocial Contract. Translated by M. Cranston. London: Penguin, 1968.

Sanderson, Robert. Lectures on Conscience and Human Law.Edited by C. H. R. Wordsworth. London: Rivingtons, 1877.

Schmitt, Carl. TheLeviathan in the State Theory of Thomas Hobbes. Westport: Greenwood Press, 1996.

Strohm, Paul. Conscience: A Very Short Introduction. Oxford: Oxford University Press, 2011.

Suárez, Francisco. A Treatise on Laws and God the Lawgiver.In Francisco Suárez, Selections from Three Works, edited by Gwladys L. Williams, Ammi Brown, John Waldron, and Henry Davis.Vol. 2. Oxford:The Clarendon Press, 1944. 


\section{Mika OJakangas}

Thomas Aquinas, Political Writings. Edited by R. W. Dyson.Cambridge: Cambridge University Press, 2002.

Thomas Aquinas. The Summa Theologica of St. Thomas Aquinas.Edited by Joseph Kenny. London: Burns Oates and Washbourne, 1920.Accessed August 24, 2012.http://www.newadvent.org/summa/

Tralau, Johan. “Thomas Hobbes contra Liberty of Conscienc." Political Theory, vol. 39, no. 1 (2011), pp. 58-84.

Tyndale, William. The Obedience of $A$ Christian Man. Edited by D. S. Daniel. London: Penguin Books, 2000.

Ward, Samuel.Balme from Gilead to Recouer Conscience. London: Roger Jackson, 1616. 